\title{
Visna Egils Skallagrímssonar
}

\section{Halldór Bjarki Einarsson ${ }^{1}$ \\ Ronni Mikkelsen² \\ Jón Torfi Gylfason ${ }^{3}$ Jan Holten Lützhøft ${ }^{4}$ \\ Höfundar eru allir læknar.}

${ }^{1}$ Heila- og taugaskurđdeild, ${ }^{2}$ taugamyndgreiningardeild, Háskólasjúkrahúsinu i Árósum, 32ækningu, Lágmúla 5, Reykjavík, ${ }^{4}$ geđrofssviði geđdeildar Háskólasjúkrahússins í Árósum.

Fyrirspurnum svarar Halldór Bjarki Einarsson, Halldor.Bjarki.Einarsson@rsyd.dk

\section{Sjúkrasaga Egils Skallagrímssonar}

Egils saga gerist á landnámsöld og er talin rituð af Snorra Sturlusyni í kringum 1230. Snemma kom í ljós að Agli svipaði mjög í útliti til Gríms (Skallagríms) föður síns og fáir voru jafn stórir sem Egill. Á einum stað segir að Skallagrímur og hans útvöldu væru heldur líkir pursum að vexti og sýn en mennskum mönnum. Ekki hafði Egill útlitið með sér; grófgerður í andliti og dökkur yfirlitum. Tekið skal fram að sú lýsing Snorra á útliti Egils parf ekki að benda til afbrigðilegs beinvaxtarsjúkdóms (skeletal dysplasia). Egill gerðist punglyndur eftir að Böðvar sonur hans drukknaði. Egill lagðist pá í lokrekkju, páði hvorki vott né purrt, og óskaði pess einfaldlega að deyja. Porgerður dóttir hans sagðist pá vilja deyja með honum. Hún lagðist við hlið hans í aðra rekkju og kom par á eftir í hann bæði sölvum og mjólk. Pegar Egill var orðinn aldraður maður gerðist hann hrumur með heyrnar- og sjónskerðingu. Fyrir utan pá hnignun og hreyfiskerðingu - en Egill var pungfær, fótstirður og fótkaldur - segir sagan að hann hafi átt pað til að missa jafnvægið og hrasa.

\section{Silfur Egils}

Egill var berserkur mikill, gríðarlega fégjarn og varð snemma stórauðugur. Pegar hér er komið sögu var Egill kominn á níræðisaldur. Pá fær hann pá hugdettu (á sama tíma og menn undirbjuggu sig til pings) að halda til pingvalla með tvær kistur fullar af ensku silfri. Pær silfurkistur höfðu honum áskotnast hjá Aðalsteini konungi eftir sigurinn á Vínheiði, ungum að árum. Færði hann aldrei föður sínum silfrið í sonargjöld eins og konungur hafði beðið hann að gera pegar hann kæmi heim til Íslands. Pess í stað dró Egill sér silfrið og bar pað með sér allar götur síðan, fram á elliár. Pá var ætlun hans undir lokin að kasta silfrinu til mannfjöldans við Lögberg og fylgjast síðan með slagsmálum manna á milli um

\begin{abstract}
Á G R I P
Ein sögufrægasta persóna Íslendingasagna er Egill Skallagrímsson. Um árabil hafa margir fræðimenn sett fram pá tilgátu að Egill hafi pjáđst af Pagets-sjúkdómi. Byggist sú tilgáta á túlkun peirra á Egils sögu. Spurningin um sannleiksgildi sögunnar vefst hins vegar fyrir og verður ekki svarað en á síðustu áratugum hefur sagnfræðigildi Íslendingasagna verið dregið mjög í efa. Pví er vert að undirstrika takmarkað̋ sagnfræðigildi Egils sögu sem og annarra sagna. Hinn einstaki frásagnarstill höfundar Egils sögu leynir sér pó ekki. Í norrænni bókmenntasögu og goðafræði koma fyrir frásagnir af hervæddri skjaldmey sem kölluð̃ var Visna. Lýsingin minnir á Egil, en höfundur peirrar frásagnar var Saxo Grammaticus sem dáđist aơ frásagnarstíl höfunda Íslendingasagna. Textatúlkun á Egils sögu sem getið er um í greininni hér fyrir neðan, beinist að tvíeðli og líkamsbyggingu Egils Skallagrímssonar. Túlkunin er á pá leið að litlar líkur séu á að Egill hafi verio pjakaður af Pagets-sjúkdómi. Pví kemur öllu heldur til kastanna ástand sem höfundar kjósa að kalla Visnu Egils Skallagrímssonar.
\end{abstract}

https://doi.org/10.17992//bl.2019.05.231

silfrið. Pess skal getið hér að Peter Hallberg, fyrrum dósent við Háskóla Íslands og síðar prófessor í bókmenntasögu við Gautaborgarháskóla, segir í bók sinni Den isländska sagan að Egill hafi lagt á ráðin um að sá silfrinu á Alpingi sér til skemmtunar eða dægrastyttingar. ${ }^{1}$ Vísar pað í ákveðna persónuleikatruflun. Fjölskylda Egils kom pó í veg fyrir pessa fyrirætlun hans. Pess í stað, og eftir að hafa mælt „vil ég fara til laugar,” hélt hann með aðstoð tveggja præla Gríms til laugar Mosfellinga með kisturnar tvær. Segir sagan að hvorki prælarnir né silfrið hafi skilað sér til baka og er kenning höfundar Egils sögu sú að Egill hafi drepið prælana tvo. En ber petta vott um minnisleysi Egils eða er mögulegt að prælarnir hafi platað veikan manninn og stungið af með silfrið?

\section{Hörpuskelin hans Egils}

Flestir geta verið sammála um að með hjálp bókmenntarýni, fornleifa- og sagnfræði auk læknisfræði sé hægt (upp að vissu marki) að varpa ljósi á ákveðið heilsufarsástand manna fyrr á öldum. Í bók sinni Hetjur og hugarvíl bendir Óttar Guðmundsson geðlæknir á að engin persóna Íslendingasagnanna falli að eins mörgum greiningum geðsjúkdómafræðinnar og Egill.² Fleiri mismunagreiningar má vissulega nefna en pær byggjast á túlkun texta úr Eglu sem gerðist fyrir um pað bil 1000 árum. Ætla má að tilgangur frásagnarinnar hafi ekki verið sá að varpa ljósi á sjúkdómafræði. Fyrirætlun höfundarins með verkinu er óljós í pessu samhengi. En eftir kristnitöku er talið að bein Egils Skallagrímssonar hafi 


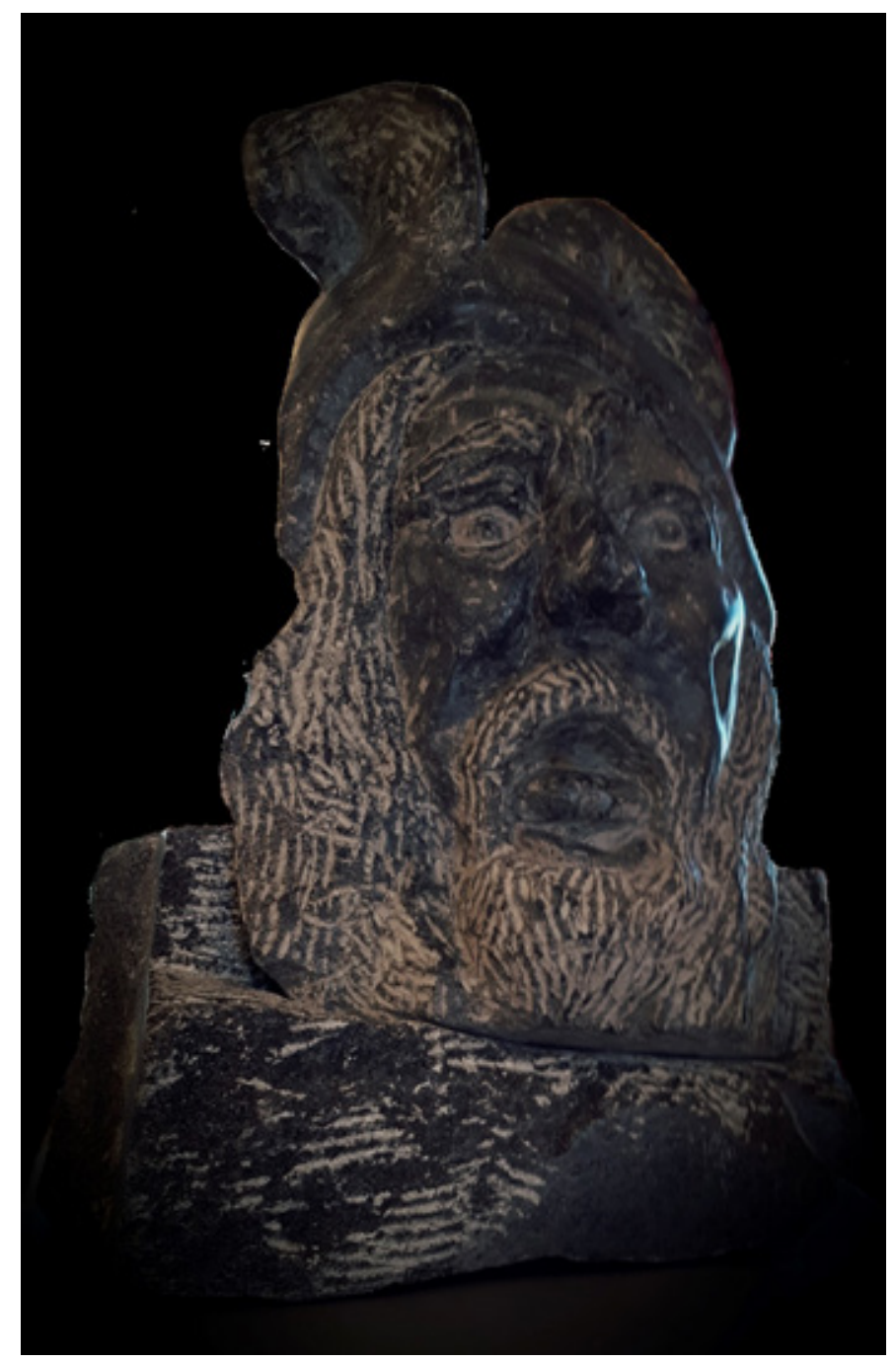

Mynd 1. Stytta eftir prófessor Magnús H. Ágústsson, listamann og lækni, frá

Kingston New York, Bandaríkjunum. Verkið gaf Magnús Landsbókasafni Íslands hinn 6. apríl árið 2000. Um er að ræða túlkun listamannsins á útliti og höfuðlagi Egils Skallagrímssonar út frá texta í Egils sögu.

fundist undir altari kirkjunnar við Hrísbrú í Mosfellsdal. Sá fundur og lýsingin á formi og umfangi höfuðkúpu Egils vísar ef til vill í afbrigðilegan beinvaxtarsjúkdóm. Pá segir að bein Egils hafi verið meiri en annarra manna og höfuðkúpan stór (mynd 1). Раð var um pað bil 150 árum eftir dauða Egils sem höfuð hans átti að hafa fundist, pungt og bárótt sem hörpuskel. Pó er frekari aflögunar beina Egils ekki getið til, eins og búast mætti við eftir útbreiddan afbrigðilegan beinvaxtarsjúkdóm. Samkvæmt Egils sögu hjó Skafti prestur Pórarinsson í höfuðkúpuna eftir fundinn með handöxi. Gaf kúpan sig ekki en hvítnaði einungis undan högginu.

\section{Uppspuni edur ei?}

Áður hefur verið fjallað um pað í Læknablaðinu að Agli hafi pótt gott að baða sig í heitri lauginni og hafi ef til vill notað laugarferðina sem yfirskin pegar hann átti að hafa falið silfrið. ${ }^{3}$ En voru heitu böðin aðal gigtarmeðferðin í fornöld? Pví er einnig spurt hvort Egill hafi verið haldinn gigtarsjúkdómi. Peirri spurningu hafa aðrir höfundar reyndar leitað svara við með greinarskrifum sín-
A

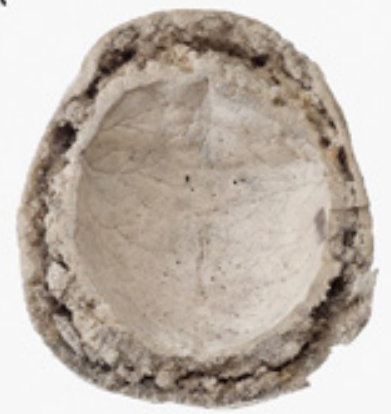

B

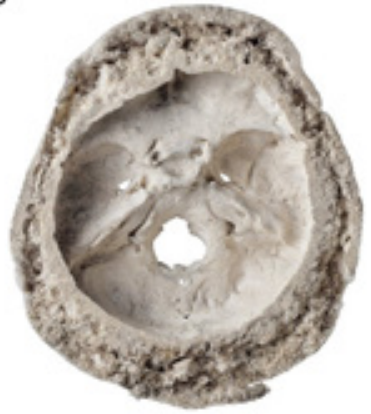

Mynd 2. Stórsætt er pað einkennandi fyrir pagetísk bein að pau eru hrjúf og stærri sökum aukinnar pykknunar samanborið við heilbrigð bein. Dykknun kúpubeins ( $A$ ) og höfuðkúpubotns (B) af völdum Pagets-sjúkdóms með fergismyndun taugaopa. Myndirnar eru fengnar úr meinafræðisafni Rudolfs Virchows. Með pakklæti til prófessors Thomas Schnalke og Christoph Weber við Berliner Medizinhistorisches Museum der Charité.

um, upphaflega í Skírni ${ }^{4}$ árið 1984 og síðar í breska læknablaðinu. ${ }^{5}$ Höfundarnir telja að Egill Skallagrímsson hafi líklega verið haldinn Pagets-sjúkdómi (osteitis deformans). Pórður Harðarson kom fyrstur manna fram með pessa tilgátu í Skírni, en eins og fram kemur í enskri grein Pórðar og meðhöfundar hans Elísabetar Snorradóttur, „Egil's or Paget's disease?“, byggja pau sjúkdómsgreiningu sína á lýsingu á Agli í hárri elli undir lok Egils sögu. Par segir að Egill hafi átt erfitt með gang og pjáðst af fótkulda. Auk pess bar á heyrnarleysi og verulegri sjónskerðingu. Jesse L. Byock, prófessor í norrænum fræðum við Kaliforníuháskóla í Los Angeles (UCLA), er sammála peim Pórði um að ofvöxtur hafi hlaupið í bein Egils sökum Pagets-sjúkdóms. Byock segir að miðað við pau einkenni Egils sem Snorri lýsir (og par með talinn fótkuldann), sé líklegt að sú sjúkdómsgreining standist. Pá má pess geta að í vísindatímaritinu Scientific American ber Byock saman einkenni Pagets-sjúkra við mismunagreiningar á borð við trefjabeinbólgu, heilkenni æsavaxtar, ennisbeinshnýfil, misvöxt bandvefs og beinholsherðingu. ${ }^{6}$ Í sömu grein er bent á að pað að höfuðkúpan hafi staðist axarhögg sé skýr tilvísun í Pagets- sjúkdóminn. Samstarfsaðili Jesse L. Byock í hinu alpjóðlega MAP-uppgraftarverkefni við Hrísbrú (The Mosfell Archaeological Project) ${ }^{7}$ frá árinu 1995, Per Holck, prófessor í líffærafræði við læknadeild Háskólans í Ósló, virðist vera honum sammála í grein í norska læknablaðinu. ${ }^{8}$ Aðrir fræðimenn hafa hins vegar talið að frásögnin um að höfuðkúpa Egils hafi staðist axarhögg kunni að vera hreinn uppspuni.

Rannsóknir mannabeina við uppgröft í tengslum við fornleifarannsóknir á Íslandi á síðustu öld má að miklu leyti pakka einskærum áhuga hins mikla velgerðamanns Pjóðminjasafnsins, Jóns Steffensen. Jón var um langt skeið formaður Hins íslenzka fornleifafélags og prófessor við læknadeild Háskóla Íslands á árunum 1937 til 1957. Haft er eftir Jóni að frásögnin um upptöku Skafta prests á beinum Egils sé um margt pjóðsagnakennd og ekki alls kostar sennileg. Petta kemur fram í ritgerðasafni hans um mótunarsögu íslenskrar pjóðar og baráttu hennar við hungur og sóttir. Jón Steffensen, sem telst án vafa meðal fremstu mannfræðinga Íslendinga, bætir hér við að „allir, er handleikið hafa hauskúpu 


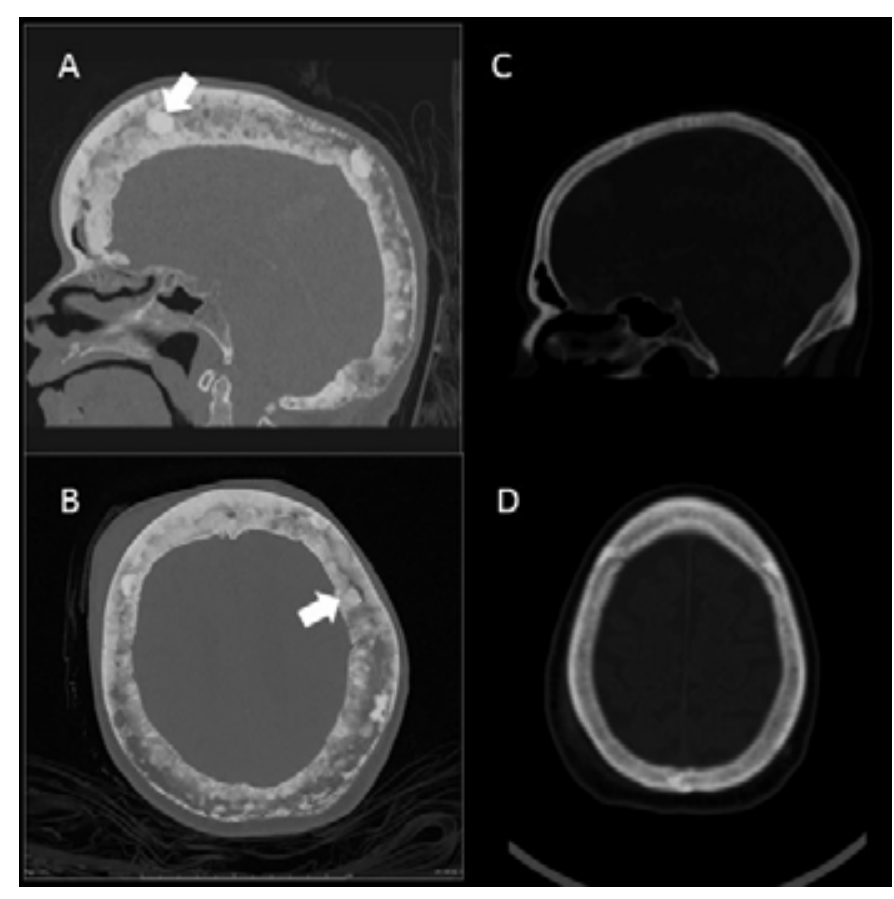

Mynd 3. Tölvusneiðmyndir með pykktar- (sagittal) og ássniðum (axial) af höfuðkúpu án skuggaefnis (beinagluggi). Pagets-sjúkdómur ( $A$ og B) sem sýnir Tam ó shanterteikn (hattur) og beinherðingarfleka (cotton wool) á milli ytri og innri hulu (theca) (hvítar pílur). Мeð pakklæti til prófessors Frank Gaillard, Radiopaedia.org, rID: 2639. Til samanburðar má sjá heilbrigða hvelfingu til hægri (C og D). Með pakklæti til myndgreiningardeildar sjúkrahússins í Randers, Danmörku. Dar sem efri hluti hvelfingarinnar samanstendur af "skeljahlutum" er við hæfi að vitna í meðhöndlun Skafta prests Dórarinssonar úr Egils sögu á beinum sem fundust við uppgröft og talið var að væru bein Egils Skallagrímssonar. En samkvæmt lýsingu i Eglu pótti „hausinn með ólíkindum pungur og allur báróttur utan svo sem hörpuskel".

gamalmennis, vita, að hún stenst ekki högg axarhamars“. ${ }^{\prime 9}$ Pá er einnig vert að minna á að engar frekari lýsingar eru um aflögun hauskúpunnar, né annarra beina í Egils sögu. Engar munnmælasögur eru heldur í sögunni um höfuðlag Egils á efri árum né að hann hafi purft æ stærra höfuðfat með árunum. Рað er vel pekkt úr sögu einstaklinga með Pagets í hauskúpu. Eins finnst Pagets-sjúkdómur í hauskúpu og í tilfelli afmyndunar hennar (leontiasis ossea) aðeins í minnihluta Pagets-sjúklinga. ${ }^{10}$

\section{Hinir fágætu beinvaxtarsjúkdómar}

Pess skal getið að yfir 20 aðrar svipgerðir með fágæta afbrigðilega beinvaxtarsjúkdóma hafa verið uppgötvaðar á síðari árum vegna breytna í erfðamenginu. Peir sjúkdómar einkennast einnig af aukinni beinpéttni og herðingu og er peim nánar lýst í tímaritinu Gene. ${ }^{11}$ Pannig hefur peirri áhugaverðu mismunagreiningu einnig verið haldið á lofti að Egill hafi verið pjakaður af Van Buchemsjúkdómnum. ${ }^{12}$

Með samantektarrannsóknum hefur komið fram að algengi Pagets-sjúkdómsins á heimsvísu sé hæst í Bretlandi og flestar greiningar í Lancashire (8,3\%) rétt norðan við Wales. ${ }^{13}$ Á hinn bóginn er hinn afar fágæti Van Buchem-sjúkdómur með undir 30 sjúkratilfelli skráð og par af er helmingurinn af hollenskum uppruna. Sjúkdómurinn er par að auki með víkjandi erfðamynstri, ${ }^{14}$ nema ef um hina enn sjaldgæfari undirgerð sjúkdómsins er að ræða (Worth- sjúkdómur), og pannig ólíklegri til sýndar svipgerðar samanborið við Pagets-sjúkdóminn. Par fyrir utan eru flestir Pagets-sjúklingar af engilsaxneskum uppruna eins og að ofan er getið. ${ }^{13,15}$ Algengi Pagets-sjúkdóms í upphafi Íslandsbyggðar er ópekkt. Рað er talið falla fremur að skandinavískum erfðum en engilsaxneskum. Pá skal pess getið að algengið mælist 0,3\% í Danmörku og Svípjóð. ${ }^{16}$ Egill Skallagrímsson tilheyrði fyrstu kynslóð Íslendinga og átti ættir sínar að rekja til Noregs. Samkvæmt grein í Lancet hefur nýgengi pagetískra tilfella í Noregi mælst enn lægra en í Danmörku og Svípjóð. ${ }^{17}$ Pótt ekki sé hægt að útiloka að ofvöxtur hafi hlaupið í bein Egils Skallagrímssonar vegna pessa sjúkdóms eða annarra fágætra og afbrigðilegra beinvaxtarsjúkdóma er hér leitast við að finna mögulegar líffræðilegar skýringar á útliti Egils og peirri hegðun hans sem lýst er í Egils sögu. Pá er hér átt við pær skýringar sem skarast á við pað hvort tilgátan um að Egill hafi verið pjakaður af Pagets-sjúkdómi hafi við rök að styðjast.

\section{Pagets-sjúkdómur}

Vitanlega er erfitt að ráđa í allar gátur Íslendingasagna og glíman við sagnfræðina par af leiðandi oft erfið. En pað vekur óneitanlega athygli að pagetísk bein reynast oft viðkvæmari en heilbrigð bein. ${ }^{18}$ Pessar niðurstöður eru pví í samræmi við athugasemdir Jóns Steffensen sem að ofan greinir. Í grein Zimmermann er pess hins vegar ekki getið hvort beinasýnin hafi verið á beineyðandi stigi (osteolytic phase), blönduðu (mosaic/mixed phase), eða beinherslisstigi (osteosclerotic phase). Ef tekið er mið af frásögninni úr Eglu um að höfuðkúpa Egils hafi staðist axarhögg má álykta að meintur Pagets-sjúkdómur Egils hafi verið á beinherslisstigi. Endanlegt svar fæst pó varla fyrr en hauskúpa Egils finnst á ný við frekari uppgröft í Mosfellsdal.

Ekki hafa fundist greinar í ritrýndum vísindatímaritum með megináherslu á fjaðurstyrkleika og beinhörku höfuðkúpu Pagetssjúklinga við vinnslu pessarar greinar. Á síðari árum er hins vegar orðið ljóst að Pagets-sjúkdómi má skipta í ofangreind prjú stig. ${ }^{19-}$ ${ }^{21}$ Sjúkdómurinn er kenndur við breska lækninn James Paget ${ }^{22}$ og lýsir sér með krónískri bólgu í beinum og óeðlilegri beinmyndun, einkum í mjaðmarbeini, hrygg, lærlegg og höfuðkúpu (mynd 2-3). Pá er hámarks nýgengi Pagets-sjúkdómsins á aldrinum 70-80 ára og í rétt rúmlega $72 \%$ tilfella er sjúkdómurinn staðbundinn (monostotic). ${ }^{23}$

\section{Meinmyndun Pagets-sjúkdóms}

Aðalorsök meinmyndunar Pagets-sjúkdómsins er ekki skýr en vitað er að beinátfrumur skipa ákveðið grundvallarhlutverk í tilurð og próunarferli hans. Pá er hún af mörgum vísindamönnum sögð tengjast mislingaveirunni. ${ }^{24-26}$ Paramyxoviridae-innlyksukorn hafa til að mynda fundist í kjörnum beinátfrumna Pagets-sjúklinga (mynd 4-5). Раð hefur síðar leitt til uppgötvunar mislingaveirumótandi-RNA-umrits með staðbundinni páttapörun. Frekari nálganir pessum líkar, pað er á staðfestingu veirumeinvalds, hafa verið gerðar með ónæmisvefjaefnafræðilegum rannsóknum og raðgreiningu mislingaveirna. ${ }^{26}$ Annar vaki af sama veiruuppruna, раð er аð segja öndunarfærasamfrymisveiran, hefur einnig fundist í beinmerg Pagets-sjúklinga. ${ }^{27}$ Tekið skal fram að Ralston bendir 
Mynd 4. Lagsjármynd (A) af fjölkjarna beinátfrumu (hvít píla) in vitro eftir Cell Tracker Green og 4',6-diamidino-2-phenylindole (DAPI)-litun. Aukin virkni og seyting beinleysihvata pessara frumna er meginástæða óeðlilegs beineyðandi ástands Pagets-sjúkdóms (fyrsta stig). Niðurrif beina $(B-C)$ með auknu uppsogi peirra og lacunae-myndun (C) hrindir af stað myndun staðboðefna sem vekja aukna virkni beinkímfrumna. Betta leiðir til blandaðs stigs sjúkdómsins og að lokum lokastigs eða óeðlilegrar beinherslismyndunar.
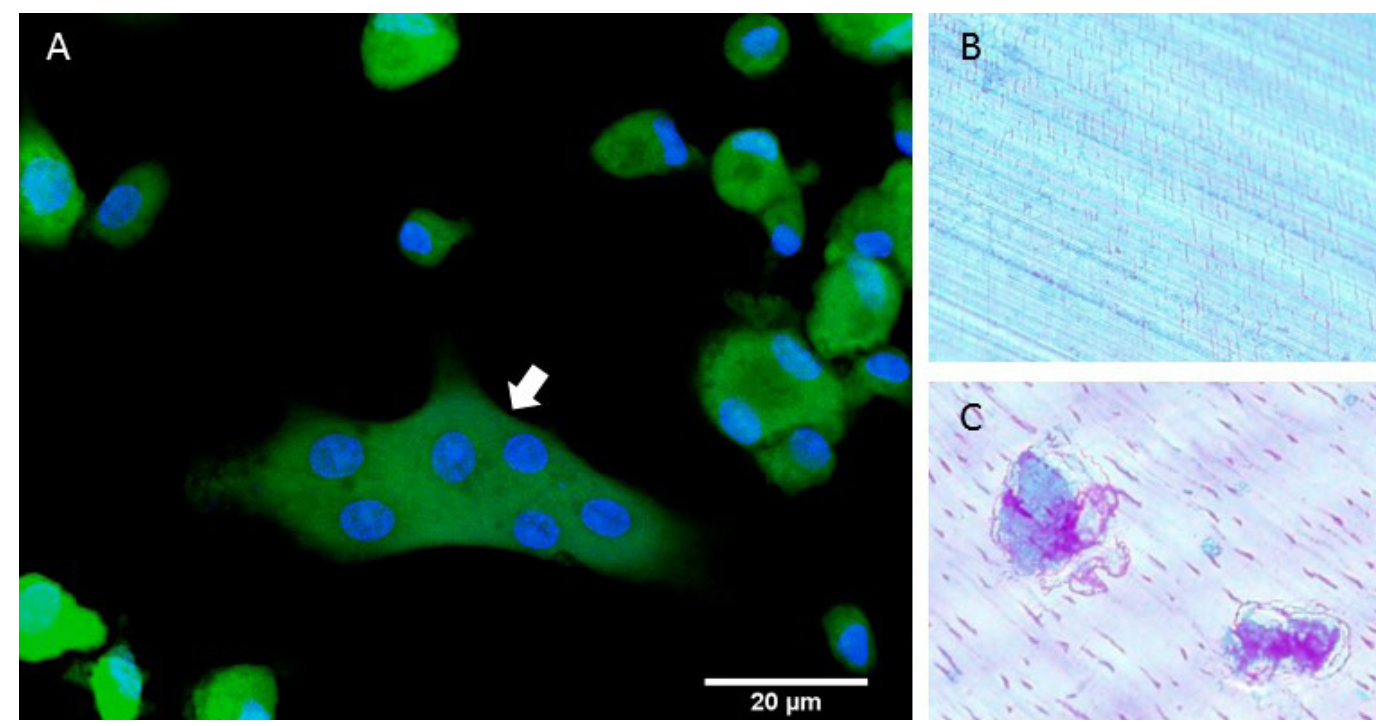

á erfðapætti sem og að ýmsar aðrar rannsóknarniðurstöður séu ekki í samræmi við pær ofangreindu. ${ }^{28}$ Par má nefna rannsóknir par sem ekki tókst að finna veirumótandi-RNA-umrit eða ónæmisvaka. ${ }^{29,30}$ Pó er ljóst að algengi Pagets-sjúkdómsins hefur minnkað frá pví farið var að bólusetja við mislingum um 1963.31,32 Pví er pörf á frekari rannsóknum á pessu sviði svo unnt sé að finna svar við tilgátunni um veiruframkallaða sjúkdómsmyndun Pagets-sjúkdómsins.

peir erfðafræðilegu pættir sem fjallað hefur verið um varða stökkbreytingu í erfðavísinum Sequestosome 1 (SQSTM1) með litningastaðsetninguna 5q35.3. ${ }^{33}$ Í Egils sögu kemur fram að Egill hafi verið mikill sem tröll, ófríður og líkur föður sínum, en ekki er unnt að vita með vissu hvort einhverjir náskyldir Agli hafa pjáðst af Pagets-sjúkdómi. Hins vegar hefur verið sýnt fram á að ættgengi SQSTM1-stökkbreytingar sé á bilinu 25-50\% og erfist hún með ríkjandi erfðamynstri. ${ }^{34,35}$ Prótínið (p62) sem genið skráir fyrir bindur við ubiquitin, en samstæðan er talin taka pátt (ásamt meðal annars RANK-L / RANK og OPG-kerfinu) í virkjun kjarnapáttar kappa-B (NF-kB)-innanfrumuboðferlis beinátfrumna. ${ }^{36,37}$ Hornsteinninn 1 myndun beinátfrumna, og eðlileg starfsemi peirra, samanstendur pannig af samruna forvera stórátfrumna (monocytes/macrophages) ${ }^{38}$ og af ofangreindu innanfrumuboðferli. Röskun í virkjun boðferlisins, vegna SQSTM1-stökkbreytingarinnar, leiðir pannig til svipgerðar Pagets-sjúkdómsins. Pá vekur pað óneitanlega athygli að sama stökkbreyting getur valdið heilabilun. ${ }^{39}$ Pví vaknar spurningin um hvort pessi erfðavísir útskýri að hluta til líkamlegt og andlegt ástand Egils Skallagrímssonar.

\section{Einkenni Egils og Pagets-sjúkdómurinn}

Í ljósi pess að fylgikvillum frá miðtaugakerfinu hefur verið lýst vegna Pagets-sjúkdóms ${ }^{40}$ má bæta við peirri vangaveltu að ekki sé útilokað að Egill hafi verið haldinn geðröskun á formi punglyndis. Byock nefnir lækkað geðslag Egils í grein sinni. ${ }^{6}$ Spyrja má hvort punglyndi Egils hafi orsakast af sonarmissinum sem sagt er frá í Egils sögu, eða hvort tilhneiging til punglyndis og andlegrar hnignunar hafi verið undirliggjandi hjá honum, pá vegna annars konar líkamlegs sjúkdóms, til að mynda Pagets-sjúkdómsins. ${ }^{40-42}$ Eins mætti segja að Porgerður dóttir hans hafi bjargað honum undan oki hugsana um dauðann, framtaksleysis, minni matarlystar og einangrunar í lokrekkju sinni með hugrænni atferlismeðferð pess tíma. Reikul hegðun og punglyndi birtist líka í ankannalegum áformum Egils um að kasta silfrinu til mannfjöldans sem fyrr segir, í peirri von að pað myndi skapa áflog og handalögmál við Lögberg. Petta tvískauta lundarfar Egils vísar pannig til geðhvarfasýki. Pá má nefna sjón- og heyrnarskerðingu Egils undir lok ævinnar, auk pess sem hann var pungfær og fótstirður. Saga um sjónleysi gæti pá vísað til gláku, sem hefur væntanlega verið algengasta orsök sjónleysis. Heyrnartap er mun meira einkennandi afleiðing Pagets-sjúkdóms pótt sjónleysi finnist einnig. Á síðustu æviárum Egils geta pessi einkenni pó varla talist einkennandi fyrir Pagets-sjúkdóm. Pví mætti gera ráð fyrir aldurstengdri sjónog heyrnarskerðingu sem mismunagreiningu við Pagets. Hvort tveggja mætti telja líklega ástæðu óstöðugleika Egils á gamals aldri. Í síðasta kvæði Egils segir:
Langt pykki mér,
ligg einn saman,
karl afgamall,
á konungs vörnum;
eigum ekkjur
allkaldar tvær,
en pær konur
purfu blossa.

Í pessari vísu Egils má skilja að „ekkjur allkaldar tvær” séu fætur hans, og hann sé pví að yrkja um fótkuldann sem hrjáði hann. 


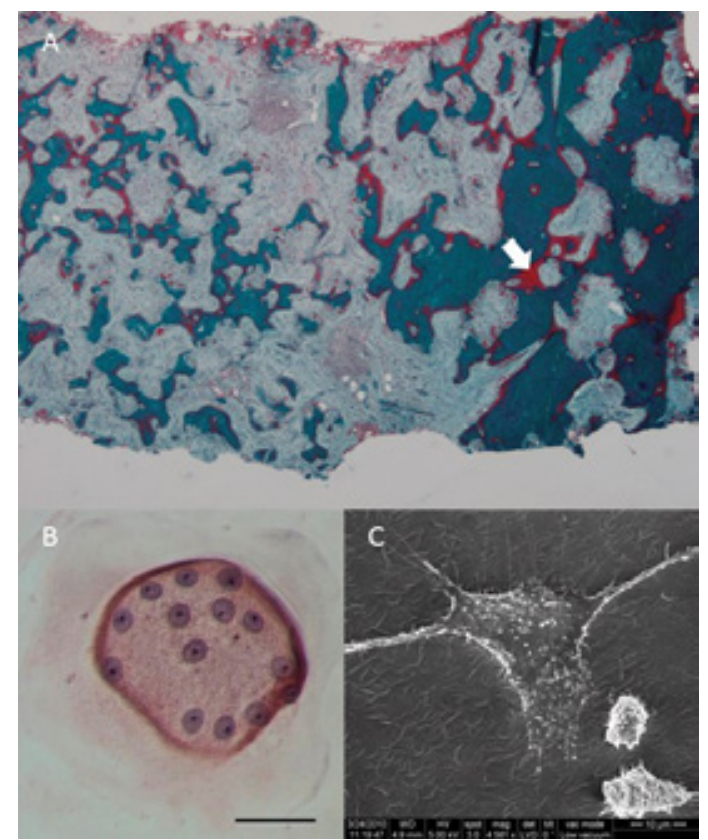

Einnig má nefna vísupartinn par á undan, úr sama kafla, par sem vikið er að getuleysi:

\section{blautr erum bergis fótar}

borr, en hlust es porrin.

Pannig er ekki ósennilegt að orsökin hafi legið í æðakölkun pegar tekið er tillit til aldurs Egils á pessum tímapunkti í sögunni. Að pessu gefnu mætti spyrja hvort blóðpurrð hafi verið að finna annars staðar í líffærakerfi hins forna víkings, svo sem blóðpurrð í ennishjarna meðfylgjandi hegðunartruflunum. Ákveðið misræmi er pó að finna í skrifum Snorra um Egil, enda segir næst á eftir ofangreindu að „, á dögum Hákonar hins ríka öndverðum, pá var Egill Skallagrímsson á níunda tigi, og var hann pá hress maður fyrir annars sakar en sjónleysis". Að pessu gefnu má draga sagnfræðigildi frásagnarinnar í efa. Ef til vill pjáðist Egill ekki af öðru en fylgifiskum ellinnar.

Vangavelturnar um blóðpurrð eru ekki í rökréttu samhengi við tilgátuna um að Egill hafði verið haldinn Pagets-sjúkdómi. Í rannsókn á 71 Pagets-sjúklingi fannst marktækt samhengi milli aukins smáæðablóðrásarflæðis í beinum og aukinni beinumsetningu. Bornir voru saman heilbrigðir einstaklingar við Pagets-sjúka og voru allir í úrtakinu á aldrinum $67 \pm 10$ ár. Pá voru pessar breytur ekki aðeins rannsakaðar fyrir höfuðkúpu, hrygg og mjaðmagrind heldur einnig fyrir útlimi. Með hjálp DCE- segulómmyndunar (dynamic contrast-enhanced $M R I$ ) sást hvar dreifing upptöku skuggaefnisins var ekki einsleit. Á hinn bóginn fundust staðbundin svæði í beinum Pagets-sjúklinga með marktæka æðavæðingu (mynd 5). ${ }^{43}$ Pessu ástandi má pannig líkja við aukið hjástreymi sem stelur blóði og flæði pess frá nærliggjandi vefjum. Рað getur pví varla útskýrt fótkulda Egils, pví samfara djúpum verkjum í fótleggjum hjá Pagets-sjúklingum verður aukinn húðhiti vegna aukins blóð- flæðis. ${ }^{44}$ Pessi práláti sjúkdómur getur einnig leitt til heyrnarleysis, blindu, erfiðleika með hreyfingu útlima vegna fergingar heilatauga auk utanhöfuðkúputaugaprengsla. ${ }^{45,46}$ Heyrnarskerðingu er pó óvanalegt að sjá koma fyrst fram í kringum níræðisaldur hjá Pagets-sjúklingum. Sú skerðing kemur vanalega fyrr fram. ${ }^{47}$ Par fyrir utan koma fyrstu einkenni Pagets-sjúkdóms að jafnaði fram á aldursskeiðinu milli fertugs og sjötugs. ${ }^{48}$ Ef tekið er mið af greinaskrifum eru 0,5\% líkur á einkennagefandi Pagets hjá Agli fyrir lok vaxtarskeiðs hans. Eins og fyrr segir er ófríðleika Egils lýst allt frá æsku til fullorðinsára og hann sagður tröll að vexti. Í pví samhengi verður að teljast líklegt að sjúkdómurinn hefði komið í veg fyrir pau afrek Egils sem getið er um í Egils sögu. Pá er einnig ólíklegt að Egill hefði komist hjá beinbrotum og afleiddri slitgigt sem hefði truflað afl og útlimahreyfingar hans.

Frá árinu 2010 hafa áhrifum ójafnvægis jónasamsetningar í blóði á hugsanir, hegðun og atferli verið gerð góð skil. Of hátt kalsíum í blóði, til að mynda vegna aukinna sviptinga í umsetningu beina, getur orsakað einkenni punglyndis, rugls og ofsóknarbrjálæðis, auk óráðs, aukins æsings og ofskynjana. ${ }^{49}$ Pað hefur hins vegar verið viðtekið lengi að péttni kalsíums í blóðsermi Pagetssjúklinga sé að jafnaði innan eðlilegra marka. Við langvarandi hreyfingarleysi og/eða beinbrot geti pað hækkað og einnig vegna kalkvakaóhófs. ${ }^{50,51}$ Par með mætti segja að fundin séu rök gegn tilgátunni um að samhengi sé á milli hegðunartruflana Egils og hugsanlegs Pagets-sjúkdóms. Nýverið hafa verið birtar niðurstöður úr pýði 236 Pagets-sjúklinga sem benda til aukinnar péttni kalsíums í blóðsermi frá 12 sjúklingum. Aðeins einn sjúklingur próaði ekki með sér afleitt kalkvakaóhóf. Hjá pessum sjúklingi mældist einungis einu sinni of há péttni kalsíums í blóðsermi. ${ }^{52}$ Að pessu gefnu má reikna með undir 0,5\% líkum á að Pagets-sjúkdómur hafi haft áhrif á hegðun og geðslag Egils.

\section{Skyggnst inn í vökvahólfin}

Á lokastigi sínu, pað er beinherslisstigi, og í tilfelli afmyndunar höfuðkúpunnar leiðir Pagets-sjúkdómurinn til fergingar heilastofns og par með myndunar vatnshöfuðs sem getur valdið heilabilun (hydrocephalus-induced dementia). ${ }^{53}$ Bent hefur verið á að pessi aflögun höfuðkúpunnar leiði til minnkunar frásogs heila- og mænuvökva frá vökvahólfum miðtaugakerfisins. ${ }^{53}$ Fjallað hefur verið um kölkun skúmkorna og hún staðfest með myndgreiningu en engar vísbendingar hafa fundist um að fyrirbærið eitt og sér geti leitt til myndunar vatnshöfuðs. ${ }^{54}$ Ályktun Moiyadi um að af- 
mynduð höfuðkúpa Pagets-sjúklings geti valdið uppsöfnun heilaog mænuvökva í kerfinu er pannig af aflfræðilegum toga í gegnum aukinn beinmassa. Eins má nefna að uppsöfnun $\beta$-amyloid getur orðið við skert flæði glymphatic- vökva í meðframæðabrautarkerfi heilans. Vökvastreymi kerfisins er pá einnig undir áhrifum slagkrafts hjartans. ${ }^{55}$ Pannig er ekki ósennilegt að slagkraftur hjartans og letjun afkasta pess valdi neikvæðum breytingum í sogkrafti kerfisins með frekari útfellingu $\beta$-amyloid peptíðs í heila og par með próun Alzheimer-sjúkdómsins. Petta bendir Bradley á í grein sinni um flæði heila- og mænuvökva hjá NPH-sjúklingum, pað er vatnshöfuðstilfella án prýstingsaukningar (normal pressure hydrocephalus). ${ }^{56}$ Heilabilun er vel pekkt hjá NPH-sjúklingum en hin tvö af prennueinkennum sjúkdómsins (oft kölluð Adams eða Hakim's triad) eru pvagleki og gangtruflanir. ${ }^{57}$

Pá segir í Egils sögu:

„Farinn ertu nú, Egill, með öllu, er pú fellr einn saman."

Burtséð frá pví hvort Egill Skallagrímsson pjáđist af teppandi eða ekki-teppandi vatnshöfði bar hann snemma einkenni reikullar hegðunar. Hins vegar er afar sjaldgæft að sami einstaklingur hafi NPH-sjúkdóm og Pagets-sjúkdóm á sama tíma. ${ }^{58}$ Við pað má svo bæta að vegna hins aukna beinmassa getur Pagets-sjúkdómurinn valdið prengslum í mænugöngum. ${ }^{40,59}$ Рað gæti útskýrt hvers vegna Egill varð pungfær og fótstirður á gamals aldri, standist tilgátan um Pagets-sjúkdóm hans. Mænuprenging vegna slitgigtar og ofvaxtar liðbands í mænugöngum (ligamentum flavum hypertrophy) á efri árum er pó mun algengari orsök peirra einkenna.

\section{Samantekt}

Síðan á landnámsöld hafa siðareglur, atferli og hegðunargildi breyst mikið en ef tekið er mið af nútímamanninum ber vígamaðurinn, bóndinn og ljóðskáldið Egill Skallagrímsson einkenni geðhvarfasýki. Á síðari hluta ævi sinnar kvartaði Egill undan fótkulda, gerðist pungfær og tapaði bæði heyrn og sjón. Pá hefur fornleifafundur sem getið er um í Egils sögu sýnt afmyndaða höfuðkúpu hans. Раð hefur leitt til peirrar kenningar að Egill hafi verið haldinn Pagets-sjúkdómi. Visna Egils Skallagrímssonar er hins vegar tvípátta tilvísun í skilning höfunda á hegðun Egils Skallagrímssonar auk líkamsástands hans, en mönnum stóð ógn af lundarfari og útliti Egils. Sama átti við um skjaldmey nokkra, Visnu, sem Saxo greinir frá. ${ }^{60}$ Með textatúlkun sinni og að teknu tilliti til misræmis í frásögn Snorra Sturlusonar af Agli hafa höfundar samtvinnað yfirferð á meinafræði og faraldsfræði Pagets-sjúkdóms. Pannig reiknast okkur til að líkurnar á að Egill Skallagrímsson hafi pjáðst af Pagets-sjúkdómi séu einungis hverfandi.

Höfundar pessarar yfirlitsgreinar vilja pakka eftirtöldum aðilum fyrir góðar ábendingar: Eva Sonja Schiøth sérfræðingur í geðsjúkdómum við öldrunargeðsvið háskólasjúkrahússins í Árósum og Nils Christian Gulmann, yfirlæknir emeritus frá sömu stofnun; Peter Johannesen, yfirlæknir, PhD við vísindastofnun Danmerkur um heilabilun við Ríkisspítalann í Kaupmannahöfn, auk adj. prófessor Ulrich Fredberg frá Diagnostisk Center við Sjúkrahúsið í Silkeborg; Hafpór Axel Einarsson sem annaðist úrvinnslu myndefnis. 


\section{Heimildir}

1. Hallberg O. De islandske Sagaer. Gyldendals Uglebøger, Denmark 1979: 119.

2. Guðmundsson Ó. Hetjur og Hugarvíl. Geðsjúkdómar og persónuleikaraskanir í Íslendingasögum. JPV Útgáfa, Reykjavík 2012: 90-5.

3. Porsteinsson J. Heitar laugar á Íslandi til forna Læknablaðið 2005; 91: 617-21.

4. Harðarson P. Sjúkdómur Egils Skallagrímssonar. Skírnir 1984;158:245-8.

5. Harðarson P, Snorradóttir E. Egil's or Paget's disease? BMJ 1996; 313: 1613-4.

6. Byock JL. Egil's bones. Sci Am 1995; 272: 82-7.

7. Byock J, Walker P, Erlandson J, Holck P, Zori D, Guðmundsson M, et al. A Viking-age Valley in Iceland: The Mosfell Archaeological Project. Medieval Archaeol 2005; 49: 195-218.

8. Holck P. Egil Skallagrimssons gård og kirke på Island fra utgravningene 2001-2005. J Norweg Med Soc 2005; 2: 340-48.

9. Steffensen J. Menning og meinsemdir: ritgerðasafn um mótunarsögu íslenzkrar pjóðar og baráttu hennar við̃ hungur og sóttir. Sögufélagið, Reykjavík 1975.

10. Drury BJ. Paget's Disease of the Skull and Facial Bones. J Bone Joint Surg 1962; 44: 174-9.

11. Aggarwal S. Skeletal dysplasias with increased bone density: evolution of molecular pathogenesis in the last century. Gene 2013; 528: 41-5.

12. Stride P. Egill Skallagrimsson: the first case of Van Buchem disease? J R Coll Physicians Edinb 2011; 41: 169-73.

13. Corral-Gudino L, Borao-Cengotita-Bengoa M, Del PinoMontes J, Ralston S. Epidemiology of Paget's disease of bone: a systematic review and meta-analysis of secular changes. Bone 2013; 55: 347-52.

14. Van Hul W, Balemans W, Van Hul E, Dikkers FG, Obee $\mathrm{H}$, Stokroos RJ, et al. Van Buchem disease (hyperostosis corticalis generalisata) maps to chromosome 17q12-q21. Am J Hum Genet 1998; 62: 391-9.

15. Wells C, Woodhouse N. Paget's disease in an AngloSaxon. Med Hist 1975; 19: 396-400.

16. Poor G, Donath J, Fornet B, Cooper C. Epidemiology of Paget's disease in Europe: the prevalence is decreasing. Bone Miner Res 2006; 21: 1545-9.

17. Falch JA. Paget's disease in Norway. Lancet 1979; 2: 1022.

18. Zimmermann EA, Kohne T, Bale HA, Panganiban B, Gludovatz B, Zustin J, et al. Modifications to nano- and microstructural quality and the effects on mechanica integrity in Paget's disease of bone. J Bone Miner Res 2015; 30: 264-73.

19. Alonso N, Calero-Paniagua I, Del Pino-Montes J. Clinical and Genetic Advances in Paget's Disease of Bone: a Review. Clin Rev Bone Miner Metab 2017; 15: 37-48.

20. Anderson DC. Paget's disease of bone is characterized by excessive bone resorption coupled with excessive and disorganized bone formation. Bone 2001; 29: 292-3.

21. Smith SE, Murphey MD, Motamedi K, Mulligan ME, Resnik CS, Gannon FH. From the archives of the AFIP. Radiologic spectrum of Paget disease of bone and its complications with pathologic correlation. Radiographics 2002; 22: 1191-216.

22. Paget J. On a Form of Chronic Inflammation of Bones (Osteitis Deformans). Med Chir Trans 1877; 60: 37-649.

23. Seitz S, Priemel M, Zustin J, Beil FT, Semler J, Minne H, et al. Paget's disease of bone: histologic analysis of 754 patients. J Bone Miner Res 2009; 24: 62-9.
24. Rebel A, Basle M, Pouplard A, Malkani K, Filmon R, Lepatezour A. Bone tissue in Paget's disease of bone. Ultrastructure and Immunocytology. Arthritis Rheum 1980; 23: 1104-14.

25. Reddy SV, Singer FR, Roodman GD. Bone marrow mononuclear cells from patients with Paget's disease contain measles virus nucleocapsid messenger ribonucleic acid that has mutations in a specific region of the sequence. J Clin Endocrinol Metab 1995; 80: 2108-11.

26. Friedrichs WE, Reddy SV, Bruder JM, Cundy T, Cornish J, Singer FR, et al. Sequence analysis of measles virus nucleocapsid transcripts in patients with Paget's disease. J Bone Miner Res 2002; 17: 145-51.

27. Mills BG, Frausto A, Singer FR, Ohsaki Y, Demulder A, Roodman GD. Multinucleated cells formed in vitro from Paget's bone marrow express viral antigens. Bone 1994; 15: 443-8.

28. Ralston SH, Langston AL, Reid IR. Pathogenesis and management of Paget's disease of bone. Lancet 2008; 372: 155-63.

29. Helfrich MH, Hobson RP, Grabowski PS, Zurbriggen A, Cosby SL, Dickson GR, et al. A negative search for a paramyxoviral etiology of Paget's disease of bone: molecular immunological, and ultrastructural studies in UK patients. J Bone Miner Res 2000; 15: 2315-29.

30. Ralston SH, Afzal MA, Helfrich MH, Fraser WD, Gallagher JA, Mee A, et al. Multicenter blinded analysis of RT-PCR detection methods for paramyxoviruses in relation to Paget's disease of bone. J Bone Miner Res 2007; 22: 569-77.

31. Matthews B, Cundy T. Paget's Disease of Bone. Expert Rev Endocrinol Metab 2009; 4: 651-68

32. cdc.gov/measles/about/history.html - nóvember 2014

33. ncbi.nlm.nih.gov/gene/8878 - febrúar 2017.

34. Hocking LJ, Lucas GJ, Daroszewska A, Mangion J, Olavesen M, Cundy T, et al. Domain-specific mutations in sequestosome 1 (SQSTM1) cause familial and sporadic Paget's disease. Hum Mol Genet 2002; 11: 2735-9.

35. Laurin N, Brown JP, Morissette J, Raymond V. Recurrent mutation of the gene encoding sequestosome 1 (SQSTM1/ p62) in Paget disease of bone. Am J Hum Genet 2002; 70: $1582-8$.

36. Cavey JR, Ralston SH, Hocking LJ, Sheppard PW, Ciani B, Searle MS, et al. Loss of ubiquitin-binding associated with Paget's disease of bone p62 (SQSTM1) mutations. J Bone Miner Res 2005; 20: 619-24.

37. Lacey DL, Timms E, Tan HL, Kelley MJ, Dunstan CR, Burgess $\mathrm{T}$, et al. Osteoprotegerin ligand is a cytokine that regulates osteoclast differentiation and activation. Cell 1998; 93: 165-76.

38. Cui W, Cuartas E, Ke J, Zhang Q, Einarsson HB, Sedgwick JD, et al. CD200 and its receptor, CD200R, modulate bone mass via the differentiation of osteoclasts. Proc Natl Acad Sci U S A 2007; 104: 14436-41.

39. Rubino E, Rainero I, Chio A, Rogaeva E, Galimberti D, Fenoglio P, et al. SQSTM1 mutations in frontotemporal lobar degeneration and amyotrophic lateral sclerosis. Neurology 2012; 79: 1556-62.

40. Poncelet A. The neurologic complications of Paget's disease. J Bone Miner Res 1999; 14 Suppl 2: 88-91.

41. ncbi.nlm.nih.gov/books/NBK1476/ - júlí 2011.
42. Dohrmann PJ, Elrick WL. Dementia and hydrocephalus in Paget's disease: a case report. J Neurol Neurosurg Psychiatry 1982; 45: 835-7.

43. Libicher M, Kasperk C, Daniels M, Hosch W, Kauczor HU, Delorme S. Dynamic contrast-enhanced MRI in Paget's disease of bone--correlation of regional microcirculation and bone turnover. Eur Radiol 2008; 18: 1005-11.

44. Shaker JL. Paget's Disease of Bone: A Review of Epidemiology, Pathophysiology and Management. Ther Adv Musculoskelet Dis 2009; 1: 107-25.

45. Devogelaer JP, Bergmann P, Body JJ, Boutsen Y, Goemaere S, Kaufman JM, et al. Management of patients with Paget's disease: a consensus document of the Belgian Bone Club. Osteoporos Int 2008; 19: 1109-17.

46. Siris ES. Paget's disease of bone. J Bone Miner Res 1998; 13: 1061-5.

47. Monsell EM. The mechanism of hearing loss in Paget's disease of bone. Laryngoscope 2004; 114: 598-606.

48. Davie M, Davies M, Francis R, Fraser W, Hosking D, Tansley R. Paget's disease of bone: a review of 889 patients. Bone 1999; 24: 11S-2S.

49. Yee AH, Rabinstein AA. Neurologic presentations of acid-base imbalance, electrolyte abnormalities, and endocrine emergencies. Neurol Clin 2010; 28: 1-16.

50. Reifenstein E, Albright F. Paget's disease: Its pathologic physiology and the importance of this in the complications arising from fracture and immobilization $\mathrm{N}$ Engl J Med 1944; 231: 343-55.

51. Brandi ML, Falchetti A. What is the relationship between Paget's disease of bone and hyperparathyroidism? J Bone Miner Res 2006; 21 Suppl 2: P69-74.

52. Wermers RA, Tiegs RD, Atkinson EJ, Achenbach SJ, Melton LJ, 3rd. Morbidity and mortality associated with Paget's disease of bone: a population-based study. J Bone Miner Res 2008; $23: 819-25$

53. Moiyadi AV, Praharaj SS, Pillai VS, Chandramouli BA. Hydrocephalus in Paget's disease. Acta Neurochir (Wien) 2006; 148: 1297-300.

54. Roche J, Warner D. Arachnoid granulations in the transverse and sigmoid sinuses: CT, MR, and MR angiographic appearance of a normal anatomic variation. AJNR Am J Neuroradiol 1996; 17: 677-83.

55. Iliff JJ, Wang $\mathrm{M}$, Zeppenfeld DM, Venkataraman $\mathrm{A}$, Plog BA, Liao Y, et al. Cerebral arterial pulsation drives paravascular CSF-interstitial fluid exchange in the murine brain. J Neurosci 2013; 33: 18190-9.

56. Bradley WG, Jr. CSF Flow in the Brain in the Context of Normal Pressure Hydrocephalus. AJNR Am J Neuroradiol 2015; 36: 831-8

57. Hakim S, Adams RD. The special clinical problem of symptomatic hydrocephalus with normal cerebrospinal fluid pressure. Observations on cerebrospinal fluid hydrodynamics. J Neurol Sci 1965; 2: 307-27.

58. Martin BJ, Roberts MA, Turner JW. Normal pressure hydrocephalus and Paget's disease of bone. Gerontology 1985; 31: 397-402.

59. radiopaedia.org/articles/paget-disease-of-bone-2 - ágúst 2016.

60. Grammaticus S. Saxo Grammaticus Danmarks Krønike. Forlaget Sesam, Viborg 2001: 309-51. 


\section{Visna of Egill Skallagrímsson}

\author{
Halldór Bjarki Einarsson ${ }^{1}$ \\ Ronni Mikkelsen ${ }^{2}$ \\ Jón Torfi Gylfason ${ }^{3}$ \\ Jan Holten Lützhøft ${ }^{4}$
}

Considering the changes in moral principles, human behavior and behavioral values through the ages, in Egill Skallagrímsson's Saga, Egill presents us with altered mental status. This is in terms of what at present is considered symptoms of an anti-social personality, and bipolar affective disorder. Egill Skallagrímsson is considered one of the most famous Vikings in the Icelandic Sagas. Archaeological findings mentioned in Egill's Saga indicate disfigurement of his skull, which has led many authors to suggest that Egill suffered from skeletal dysplasia. The primary assumption in the literature is that Egill Skallagrímsson was affected by Paget's disease of bone. This consideration is additionally based on the scholar's interpretation of the Saga text. The unique storytelling style in the Saga of Egill Skallagrímsson is evident; however, the question of the story's truthfulness remains open. In this article, we investigate Egill Skallagrímsson's assumed Paget's disease of bone, based on the physical and mental symptoms disclosed in the Saga of Egill Skallagrímsson. Associated with the assumption, the author's hermeneutics of Egill's Saga in the context of modern-day knowledge of Paget's disease of bone, brings forward the probability estimate to the range of permille. In Scandinavian folklore and mythology, a tale by Saxo Grammaticus of a notorious shield-maiden named Visna, reminds of Egill, as noted by Snorri Sturluson. Hence, in reference to Egill Skallagrímsson's mental status and physical appearance as listed in Egill's Saga, the authors recommend the name for his condition to be "Visna of Egill Skallagrímsson".

'Department of Neurosurgery, Odense University Hospital, Denmark, ${ }^{2}$ Department of Neuroradiology, Aarhus University Hospital, Denmark, ${ }^{3}$ Lækning, Lágmúla 5 , Reykjavik, Iceland, ${ }^{4}$ Department of Psychiatry, Aarhus University Hospital, Denmark.

Key words: Egill Skallagrimsson, skeletal dysplasia, Paget's disease of bone, bipolar affective disorder, hydrocephalus, dementia.

Correspondence: Halldór Bjarki Einarsson, Halldor.Bjarki.Einarsson@rsyd.dk 